\title{
European Politics and the Neoliberal Paradigm
}

\author{
KRZYSZTOF SLIWINSKI \\ Hong Kong Baptist University, HK \\ chris@hkbu.edu.hk
}

\begin{abstract}
This paper looks at the European integration project in its current iteration drawing on Karl Polanyi's assertion that markets are inseparable from the socio-cultural context. In this regard, all attempts to liberalise the economy (not excluding European integration, which is based on the principle of the single market) have practical and indeed tangible political ramifications. The main hypothesis of the paper lies in the recognition of the fact that the neoliberal agenda is one of the defining features of European integration. It is after all, the project of the single market, with its free movement of goods, services, capital, and labour that underpins European Union integrative practice.
\end{abstract}

Secondly, it is the presupposition of this paper, that there is a certain degree of congruence between the economic elites, operating within the neoliberal framework, and the centre-left political elites. The argument here is that the logic of neoliberalism has been fundamentally accepted across the mainstream of the political spectrum. This consequently means that even left-wing parties have had to reposition themselves both ideologically and practically, which brings the conclusion that the market has lost its role as the basic ideological differentiator between the traditional right and left. The axis of political debate has consequently shifted to moral issues such as the relationship between the state and the church, immigration, and gender.

Keywords: EU; neoliberalism; democracy deficit; political ideologies

\section{Introduction}

On 12th October, 2016 Euractiv.com reported on a peculiar piece of news. According to one of the biggest European media platforms, more than 150,000 European Union (EU) officials and citizens had signed a petition demanding that the pension rights of former European Commission President José Manuel Barroso should be suspended for accepting a job at Goldman Sachs (Euractiv, 2016). According to the petition by EU staff: "This decision to go and work for one of the banks most implicated in the subprime crisis that led to the financial crisis of 2007-2008 - the worst since the Great Depression - as well as one of the banks most involved in the Greek debt crisis, having helped Greece dissimulate its deficit before speculating in 2009-2010 against it in full knowledge of the unsustainability of its debt, is a further example of the irresponsible revolving-door practices, which are highly damaging to the EU institutions and, even if not illegal, morally reprehensible" (change.org).

Admittedly, this is not the only case that has stirred controversies regarding the ethics both of former and current high-ranking officials of the European Commission. The Alliance for Lobby Transparency and Ethics Regulation (ALTER-EU) lodged a formal complaint to the President of the European Commission referring to the practice of the 
so-called "revolving door" phenomenon - the movement of personnel between roles as legislators and regulators and the industries affected by the legislation and regulation. Apparently, the European Commission did not act when Ms Neelie Kroes (a former European Commissioner for Digital Agenda and a European Commissioner for Competition) joined the public policy advisory board of Uber (an American worldwide online transportation network company) and the board of directors of Salesforce (an American loud computing company). The European Commission also did not act when the former Trade Commissioner Mr De Gucht joined the board of Arcelor Mittal (a Luxembourg-based multinational steel manufacturing corporation, and a major EU lobbyist). Furthermore, ALTER-EU claims that these three cases prove not only the vagueness of the Code of Conduct for the Commissioners and the inadequate implementation of Article 245 of the Treaty on the Functioning of the European Union, but also demonstrate a failure on the part of the Commission to even recognise the problem (Alliance for Lobbying Transparency and Ethics Regulation, 2016). Consequently, ALTER-EU proposes a reform of the "revolving door" rules in the existing Code of Conduct; this reform needs to extend the cooling-off periods for former Commissioners and provide a better definition of lobbying as well as revise the appointment procedures to an ad hoc ethical committee.

Whether or not these cases are isolated, they are highly controversial since they include the highest-ranking officials of the regulating body of the EU. Amid recent calls from France and Germany to deepen the project of European integration and move towards a federation, it is vital to analyse and once again question the normative basis of European integration in the economic domain. It seems that the mainstream of the European civil service and most national political elites have accepted the phenomenon of globalisation with all its economic and political consequences as being the only viable solution. In other words, the existing European establishment is either not capable or not willing to propose alternative solutions that would aim to tackle the economic and social challenges.

This paper looks at the European integration project in its current iteration, drawing on Karl Polanyi's assertion that markets are inseparable from the socio-cultural context. In this regard, all attempts to liberalize the economy (not excluding European integration, which is based on the principle of the single market) have practical and indeed tangible political ramifications. The main hypothesis of this paper lies in recognizing the fact that the neoliberal agenda is one of the defining features of European integration. It is, after all, the project of the single market with its free movement of goods, services, capital, and labour that underpins EU integrative practice. Secondly, it is the presupposition of this paper that there is a certain degree of congruence between the economic elites, operating within the neoliberal framework, and the centre-left political elites. The major question that this paper addresses is the consequences of the suggested ideological shift by the mainstream European political elites for the European societies and in particular for the European identity and the future of the EU.

Neoliberalism is referred to herein as an ideology which denotes a concept of freedom as an overarching social value associated with reducing the state's functions to those of a minimal state. Furthermore, terms such as: "neoliberal paradigm" and "neoliberal agenda" or "neoliberal perspective" are used to denote different aspects of the very same ideology. Two more notions are used throughout the paper: "economic elites" and "Political elites". Both are used in a narrow sense. The term "political elites" is 
applied in a strictly formal manner and refers to political parties and their representatives in power. As for the term "economic elites" it refers to the whole amalgam of economic actors that are capable of influencing (lobbing) the decisionmaking process both on national as well as European levels.

The first segment of the paper analyses the ideological grounds of European integration from the liberal perspective. In doing so, it draws upon both the regional European determinants and the larger international circumstances that have led to the international liberalisation of trade. To facilitate the argumentation, examples of influence by big business and lobbying are invoked. Given the limited nature of this paper the above mentioned illustrations do not and in fact cannot pretend to represent the whole picture. Yet, they have been applied here as important cases that are capable of confirming a hypothesis which claims that neoliberalism is one of the defining features of European integration - the emphasis being on one of, not the prevailing one or the exclusive one. It is understood thus that the processes of European integration are multifaceted and therefore bear many, sometimes even contradictory characteristics. The focus of this study is revolving around the role of the market forces in European integration and the consequences of such for European politics at large as well as European societies.

Next, special attention is paid to the context regarding the negotiations of the Comprehensive Economic and Trade Agreement (CETA). The major line of the argument is that these agreements, controversial in their content but more importantly due to the secrecy surrounding the negotiation process, should raise serious concerns regarding the EU citizenship capacity.

Last but not least, the example of the Eurozone is employed in order to strengthen the argumentation, which based on the criticism of neoliberalism, helps the reader in understanding not only the fallacy of the single currency concept, but more importantly in making a link with the political accountability and democratic challenges. The following segments of the paper, while revolving around the issue of democratic representation, focus on the shift in political ideologies between the major European political parties. The argument here is that the logic of neoliberalism has been fundamentally accepted across the mainstream of the political spectrum. As a result, even left-wing parties have had to reposition themselves both ideologically and practically, which brings the conclusion that the market has lost its role as the basic ideological differentiator between the traditional right and left. The axis of political debate has consequently shifted to moral issues such as the relationship between the state and the church, immigration, and gender. This, has far reaching consequences for "European identity".

\section{Neoliberalism and the project of European integration}

The end of the Cold War facilitated the speeding-up of the processes of globalisation, especially in its economic domain. The so-called "Washington Consensus" (WC), a set of policy recommendations which aimed to deregulate finance and trade, became the new global standard. The peace dividend, heralded after the end of the Cold War, allowed for a market-based approach to dominate numerous aspects of politics and also international relations. No more competition, "let's talk business", became the new modus operandi. Neoliberalism therefore entered its next stage where economics finally overshadowed politics. As William Davies (2014) acutely observes: “... the 
character of neoliberal authority: on what basis does the neoliberal state demand the right to be obeyed, if not on substantive political grounds? To a large extent, it is on the basis of particular economic claims and rationalities, constructed and propagated by economic experts. The state does not necessarily (or at least, not always) cede power to markets, but comes to justify its decisions, policies and rules in terms that are commensurable with the logic of markets." What it means in practice for foreign policy-makers in the 21st century is that ideological differences are no longer barriers to trade and therefore pragmatism becomes not only an overwhelming narrative but can even be elevated to the level of a normative basis.

The history of European integration starts with a project carried out under the banner of functionalism. The first community - the European Coal and Steel Community was to a large extent also an economic project that would allow the foundations to be laid for the future creation of a free trade area and a common market (Nugent, 2010). The subsequent creation of the European Economic Community (EEC) firmly established economic cooperation based on the liberalisation of the markets. As Article 2 of the EEC treaty (the treaty which established the EEC in 1957) clearly stated: "the community shall have as its task, establishing a common market and progressively approximating the economic policies of member states, to promote throughout the community a harmonious development of economic activities, the continuous and balanced expansion, an increase in stability, an accelerated raising of the standard of living and close relations states belonging to it”. Article 3 further elaborates on the practical steps to be taken in order to achieve the stated goals. These steps, among others, included: the elimination of customs duties and quantitative restrictions; the establishment of a common customs tariff; the abolition of obstacles to the free movement of persons, services, and capital; the inauguration of a common agricultural policy; the inauguration of a common transport policy; the establishment of a competition policy; and the establishment of procedures to tackle the imbalance of payments between Member States. The preamble of the treaty explicitly states, inter alia, that the EEC falls within the general logic of the progressive abolition of restrictions on international trade.

Let us keep in mind that the years 1955 and 1956 saw the fourth round of the General Agreement on Tariffs and Trade, the so-called Geneva Round, where 26 countries participated and US\$2.5 billion in tariffs were eliminated or reduced. Subsequent rounds, which included more countries and pushed the reductions further, created the general framework in the global scope for the liberalisation of trade. It was obvious to the Europeans, from the early years onwards, that amid a globalizing world they had to pool their economic resources to stay competitive. Especially painful was the realisation of the economic cooperation limitations within the EEC vis-à-vis the oil shock of 1973 as well as the end of the Bretton Woods system, which brought currency vulnerabilities. These events are usually referred to in the literature as the "Eurosclerosis of the 1970s" and they brought to the forefront the need to deepen economic cooperation and prepare the ground for monetary cooperation (Staab, 2011). The 1980 s made it clear that deepening cooperation between the European markets was the only way to remain competitive in an international economy, given Japanese and American economic growth. The world has in that sense become only more competitive since then. The EU bureaucracy has recently confirmed the apparently unavoidable trends of such nature in its latest, as of July 2017, document regarding the future of the EU. "The White Paper on the future of Europe: avenues for unity for the EU at 27", as announced by President of the European Commission, Jean-Claude 
Juncker, identifies the processes of globalisation and economic competitiveness as one of the underlying and indeed fundamental factors that are shaping the international environment. Let us take a closer look at the document, which still remains the official stance of many of the EU political elites on the challenges Europe is expected to face by 2025 .

In its second part entitled: The drivers of Europe's future - a changing place in an evolving world, the opening salvo takes the reader right into the middle of the economy-related arguments: "Europe is home to the world's largest single market and second most used currency. It is the largest trade power and development and humanitarian aid donor. [...] While the world has never been smaller or better connected, the return of isolationism has cast doubts over the future of international trade and multilateralism. Europe's prosperity and ability to uphold our values on the world stage will continue to depend on its openness and strong links with its partners. Yet, standing up for free and progressive trade and shaping globalisation so it benefits all will be a growing challenge. [...] The White Paper looks at how Europe will change in the next decade, from the impact of new technologies on society and jobs, to doubts about globalisation, security concerns and the rise of populism. It spells out the choice we face: being swept along by those trends, or embracing them and seizing the new opportunities they bring. Europe's population and economic weight [is] falling as other parts of the world grow. By 2060, none of our Member States will account for even 1\% of the world's population - a compelling reason for sticking together to achieve more." (White Paper on the future of Europe: Reflections and scenarios for the EU27 by 2025).

The document puts forward five possible scenarios for EU Member States to follow: (a) "Carrying On" - where the EU27 focuses on delivering its positive reform agenda in the spirit of the Commission's New Start for Europe from 2014 and of the Bratislava Declaration agreed by all 27 Member States in 2016; (b) "Nothing but the Single Market" - where the EU27 is gradually re-centred on the single market as the 27 Member States are not able to find common ground on an increasing number of policy areas; (c) "Those Who Want More Do More" - where the EU27 proceeds as today but allows willing Member States to do more together in specific areas such as defence, internal security, or social matters. Consequently, one or several "coalitions of the willing" emerge; (d) "Doing Less More Efficiently" - where the EU27 focuses on delivering more and faster in selected policy areas, while doing less where it is perceived not to have an added value. Accordingly, attention and limited resources are focused on selected policy areas; and (e) "Doing Much More Together" - where, Member States decide to share more power, resources, and decision-making across the board. Decisions are agreed faster at the European level and are thereafter rapidly enforced.

Given President Juncker's role, his political affiliations and numerous earlier speeches, observers are probably right to assume that the most favoured scenario would be scenario number five, also referred to as the "Verhofstadt scenario" (named after the MEP and former Belgian Prime Minister Guy Verhofstadt, a leading proponent of federalism). Cooperation between Member States would, according to this option, go further than ever before in all domains (Politico, 2017). As Bartholomeusz observes, "[...] it is clear from the tone of the White Paper where the institution's sympathies lie. In these matters, Juncker and his team are absolutely right: only federal integration can create a sustainable future for Europe. Why are the other options not serious 
possibilities? Because they will both, sooner or later, lead to the collapse of the EU itself" (Bartholomeusz, 2017).

Likewise, Guy Verhofstadt himself has recently proposed that the European Commission should be abolished. In its place should be created a small European government (Die Zeit, 2017). In his own words: "WE CANNOT CONTINUE to stand separately and muddle along like this while globalisation mercilessly batters our member states' national sovereignty. Whether in relation to the banking crisis, global warming, international fraud, or organised crime, anyone seeking an effective solution to these issues inevitably concludes that one exists only at the European level. Thus we must opt for stronger European institutions and a federal European state.

In fact, globalisation necessitates the advent of this sort of federal Europe. And globalisation is only going to gather speed [...] As a consequence of the world we live in, integrating is no longer an option; it is a necessity" (Verhofstadt, 2017).

\section{Big business and influential individuals}

One of the most interesting examples of how big business influences European politics is the Brussels Economic Forum (BEF). It is, as one can read on the official website of European Commission, a flagship annual economic event. The BEF brings together top European and international policy-makers and opinion leaders as well as civil society and business leaders. It is the forum at which to take stock of economic developments, identify key challenges, and debate policy priorities. The BEF attracts a thousand participants every year and broad media coverage, and it provides a major networking opportunity (European Commission, Economic and Financial Affairs, 2017). One of the key speakers during its latest session (1st June, 2017) was George Soros - founder and Chair of Soros Fund Management LLC and the Open Society Foundations. In his speech delivered at the BEF, Soros identified three problem areas where he urged European policy-makers to achieve what he termed "a meaningful progress". These areas include: the immigration crisis; territorial disintegration (Brexit); and the lack of an economic growth policy (Remarks at the Brussels Economic Forum, 2017). As such, the document seems objective and even constructive.

One should, however, bear in mind that, apart from being a successful funds manager, Soros has been involved in bringing down both the British Pound in 1992 and the Thai Bhat in 1997 (which latter act allegedly led to Asian Financial Crisis in 1998 (Business Insider, 2016)), and he is a strong supporter of massive immigration from North Africa and the Middle East to Europe. In the middle of 2015, amid the beginning of the immigration wave that has reached Europe, Project Syndicate published an article, in which Soros proposed a six-point plan that in its last point postulated: "First, the EU has to accept at least a million asylum-seekers annually for the foreseeable future. And, to do that, it must share the burden fairly [...] Adequate financing is critical. The EU should provide $€ 15,000$ (US $\$ 16,800$ ) per asylum-seeker for each of the first two years to help cover housing, health care, and education costs - and to make accepting refugees more appealing to member states (author, 2016).

Arguably, George Soros promotes a particular version of a borderless society that fuses progressive social ideas supported by the European left and economic conditions that draw heavily on the ideology of neoliberalism. His foundations, or the institutions that they support more or less openly, are in fact parties to ideological and political conflicts 
in countries such as the USA, Russia or even China. Interestingly, in the case of Hungary or Poland, unlike the way in which the mainstream so-called liberal media like to present it, Soros is able to influence public discourse overtly or covertly supporting the political opposition against legally elected governments, supported by the majority of voters, that happen to emphasise national interests - the case of the Central European University in Hungary or the daily Gazeta Wyborcza (Electoral Newspaper) in Poland. The latter is in fact an exemplar of a reactionary, postcommunist platform, through which all sorts of "modern", "European" or even "international" arguments are cynically and instrumentally used against the government of Law and Justice in the ideological battle between the former left on the one hand and centre-right and the right on the other.

\section{Eurozone challenges}

Perhaps the most tangible symbol of European economic integration, as well as of the economic crisis, is the European single currency - the Euro. Historically speaking, a single currency had been on the minds of the European political elites for quite some time. Not surprisingly, arguments in favour of the creation of monetary union were largely, economically speaking at least, based on the liberal agenda: "a single currency offers advantages, such as eliminating fluctuating exchange rates and exchange costs. As it is easier for companies to conduct cross-border trade and the economy is more stable, the economy grows and consumers have more choice. A common currency also encourages people to travel and shop in other countries. At global level, the euro gives the EU more clout, as it is the second most important international currency after the US dollar" (europa.eu).

Eighteen years after the creation of the Eurozone (on 1st January, 1999), the single currency is still far from delivering its promised benefits. Huge inequalities within the Eurozone itself, high unemployment (especially among the young), the loss of job security, the consequent emergence of a new social class (the "precariat"), very low inflation, and economic stagnation or minimal growth are trademarks of the general economic problems in the EU, and they are even worse in the Eurozone countries. As Joseph Stiglitz suggests: "In a sense, then, the story of the Eurozone is a morality play: It illustrates how leaders out of touch with their electorates can design systems that do not serve their citizens well (Stiglitz, 2016). There is no doubt here that one of the greatest economists of our time is not only heavily criticizing the foundations of the monetary union, but he also defines the ideology of neoliberalism as the single most important nonmaterial factor that has led to the biggest economic crisis of the 21st century to date, which as we have seen has had dire consequences for the Euro and the EU economies.

Paul De Grauwe of the London School of Economics echoes this position. In a widely cited paper on the design of the Eurozone, he says: "[...] the endogenous dynamics of booms and busts that are endemic in capitalism continued to work at the national level in the Eurozone and that the monetary union in no way disciplined these into a unionwide dynamics. On the contrary the monetary union probably exacerbated these national booms and busts" (De Grauwe, 2013).

Economic problems coupled with a growing wealth gap have prompted many to question the normative basis on which the EU project has until recently been carried out. Criticisms have come even from the UK, in the eyes of some a most unlikely source. 
As Michael Rustin of Soundings rightly observes: "The fact is that the principles of the free movement of labour and capital, which have been quite central to the idea of the European Union, represent the implementation on a European scale of the doctrines of neoliberalism. These principles are, and always have been, quite insufficient for the regulation of capitalism in democratic societies".

\section{Lobbying}

For years, lobbying has been an important part of European policy-making. Recently, with the Lisbon Treaty, lobbying has been institutionalised in the EU. It is officially termed "European interest representation" and is made part of the legislative process under the framework of the new participatory democracy of the EU.

According to the UK-based ALTER-EU (a coalition of over 200 public interest groups and trade unions) between 25,000 and 30,000 professional lobbyists at any time populate the corridors of the EU institutions. Allegedly, a large majority represent business interests. The ALTER-EU claims that the influence of corporate lobbyists on EU policy-making has largely remained out of public sight, and therefore the influence granted to corporate lobbyists in EU decision-making stirs serious concerns about the impartiality of EU decision-making and its democratic principle (Alliance for Lobbying Transparency, 2017).

Furthermore, the Brussels-based Corporate Europe Observatory (CEO), a non-profit research and campaign group, which campaigns for transparency in European corporate lobbying, publishes regular information on the environment, economy and finance, food and agriculture, international trade, and the "revolving doors" phenomenon. Their "revolving door watch" makes important reading for all those who are interested in what the commissioners, members of the European Parliament, and other EU officials do when they stop working for the EU institutions (Corporate Europe Observatory, 2017). For example, according its website, in a vital for social Europe domain - healthcare, privatisation has been ready across Europe's health services (Tansey, 2017). Marketisation, trade policy, public-private partnership, and "economic governance" are all culprits of the incremental encroachment of an increasingly privatised model of healthcare provision across Europe.

Alarmingly, as we can learn from LobbyFacts.eu: "The private sector has more organisations lobbying the EU, spends more on lobbying, and deploys more lobbyists than NGOs and trade unions. In the Parliament, the analysis of the number of lobbyists shows that the corporate sector has 60 per cent more than that of civil society. If you factor in lobby consultancies, the imbalance becomes even more stark" (Cann, 2017). 


\section{CETA - the democracy deficit}

On 3oth October 2016, the day on which CETA was finally signed, Guy Verhofstadt declared on his Facebook account: "I am happy that European and Canadian leaders formally signed their EU-Canada free trade pact today. In times of increasing globalisation, a retreat to protectionism will make us poorer. We should use agreements like \#CETA to set the framework and rules for global connectivity ourselves." ${ }^{1}$ The then President of the European Parliament Martin Schulz and the President of the European Commission have been also openly enthusiastic, indicating the new "benchmark" in EU-Canada relations as well as the "golden standard" in international trade agreements. ${ }^{2}$ The President of the European Council Donald Tusk went even further, declaring on his Twitter account: "Free trade and globalisation have protected humanity from poverty, hunger and total conflict. Few people seems [sic] to believe this today.","3

The list of counterarguments against CETA is lengthy. The many opponents of the CETA between the EU and Canada prominently feature The Greens-European Free Alliance in the European Parliament (Greens/EFA), who resolutely oppose CETA for twelve reasons. These reasons are not only fundamentally important from the procedural standpoint but they principally refer to the content of the agreement. According to The Greens, unlike in the case of TTIP, during the CETA negotiations the European Commission never released the documents before the final text of the agreement was published (The Greens/European Free Alliance, 2017). The European Parliament members and parliamentarians across Europe alike could not therefore have access to the text while it was being negotiated, thereby depriving European societies of their basic right to scrutinise the policy-making process. ${ }^{4}$ Furthermore, the Green/EFA claims that, particularly worrying, are those stipulations which provide for investor-state dispute settlement (ISDS), which allows foreign investors to sue nations if they feel that their businesses have been impacted by new laws or regulations. ${ }^{5}$ Other concerns include: locking-in current and further liberalisation, thereby making it very difficult (and costly) for countries to bring services back into public ownership; increased costs to public healthcare systems due to changes in patent protection for pharmaceutical drugs; further contribution to the pro-GMO (genetically modified organisms) pressure on the EU regulatory processes; weakening the Fuel Quality Directive (FQD), which is allegedly a crucial piece of law aimed at reducing the EU's carbon emissions; weakening the rules which aim to benefit local communities and municipalities in terms of employment and sustainability; procuring the facilitation of only the "most beneficial" or "the cheapest offer" mechanisms when tendering; providing no binding rules to protect and improve workers' rights and environmental protection; introducing further completion mechanism which will probably affect farmers; containing pro-industry provisions

\footnotetext{
${ }^{1}$ See: https://www.facebook.com/GuyVerhofstadt/

${ }^{2}$ See: https://twitter.com/JunckerEU

3 See: https://twitter.com/eucopresident

4 See: Aline Robert (13th October, 2016).”Strange" maneuvering over CETA exposes democratic deficit. Euractiv Retrieved from http://www.euractiv.com/section/trade-society/news/strange-maneuvering-over-ceta-exposesdemocratic-deficit/

5 This is a particularly controversial mechanism. For more information and analysis please see: Michael Geist, The devil's in CETA's details, specifically on dispute settlement, The Globe and Mail, 25th October, 2016 Retrieved from https://www.theglobeandmail.com/report-on-business/rob-commentary/the-devils-in-cetas-detailsspecifically-on-dispute-settlement/article32492826/
} 
which curb the regulatory space for governments to act with regard to the Paris Agreement provision limiting $\mathrm{CO}_{2}$ emissions; and, finally, expanding foreign investorrights tenfold, which may result in $81 \%$ of US subsidiaries in the EU being able to launch ISDS attacks with CETA alone.

Interestingly, concern is growing among Canadians as well. As Citizens Against CETA (a Canadian-based citizen action group) claim, the Canadian government continues to maintain that CETA will boost Canada's economy by 12 billion Canadian Dollars and create 80,000 jobs (Citizens Against CETA, 2017). These figures were apparently generated by manipulating the results of a 2008 computer model built by three European economists retained by the Canadian and the EU governments. As such, it is claimed that it has serious flaws: it assumes full employment; total reinvestment of trade gains into new production; balanced trade; and Canadian corporations doing as well in Europe as European corporations are doing in Canada. It does not take into consideration the impact of currency fluctuations and also it predates the economic crash of 2008 (Economic prosperity based on a flawed computer model, 2013).

\section{The shift of paradigms}

Now that we have established the empirical evidence that indicates the fundamental link between the liberal paradigm and the European integration processes, let us turn our attention to European politics and specifically to the European political parties both at the national and the European levels. As put forward before, the major presumption of this paper is that the traditional divide between the left and the right, which stems from the attitudes towards the role of the state in managing the markets, is no longer relevant in understanding contemporary European politics. Today, most mainstream political parties, both those on the right and those on the left, have fundamentally accepted the free-market paradigm and therefore the processes of globalisation. As Martin Schulz, the then president of the European Parliament, observed when commenting on CETA: "CETA is a good agreement. Globalisation needs rules, [...] "If there is an error we can make today is not to vote for CETA, [...] The government in Sweden (left supported by the greens), the government in Lisbon (supported by the left wing and communist party), the governments in Italy, France, Austria, Slovakia, Czech Republic - all socialist parties are in favour, [...] "These are left wing leaders in Europe. We are in favour for it.” (Euraciv, 2017).

This requires a further look into the European left-wing political parties' platforms and an analysis of their evolution since the 1980s. Traditionally, leftists [...] claim that human development flourishes when individuals engage in cooperative, mutually respectful relations that can thrive only when excessive differences in status, power, and wealth are eliminated. According to the leftists, a society without substantial equality will distort the development not only of deprived persons, but also of those whose privileges undermine their motivation and sense of social responsibility. This suppression of human development, together with the resentment and conflict engendered by sharp class distinctions, will ultimately reduce the efficiency of the economy (Clark, 1998). From the traditional left (socialist) concern for the weak and vulnerable in society (welfare concern, redistribution, and social justice), influenced by a Keynesian-based stance that capitalism could be "humanised" (beliefs especially adhered to after the Second World War (WWII), social democrats have evolved greatly; they had in fact already abandoned many of their original values by the 1980 . The socalled "third way" has been one of the major features of this evolution. Although 
notoriously imprecise and subject to various interpretations, it is characterised by four prominent attributes: (a) top-down state intervention is a dead-end, and consequently there is no alternative to "a dynamic market economy"; (b) acceptance of the processes of globalisation as a major economic and social force in the contemporary world; (c) a shift in the role of the government to promote the competitiveness of society through education and the strengthening of civil society, and finally, (d) the abandonment of socialist egalitarianism, and, instead, the embracing of the liberal ideas of equality of opportunity and meritocracy (Heywood, 2002).

Accordingly, as Tom Angier in Social Europe argues: "[...] we face a problem of great historical moment: namely the European left's abandonment of its core constituency. Since the 1980s, the working classes have been progressively deprived of a political voice, a situation exacerbated by the increasing 'immiseration' of those still clinging to the label 'middle class'. In the face of such downward mobility, those who might have stood up to the emerging status quo have engaged, instead, in a full-scale retreat. And this has taken place on two main fronts" (Angier, 2015). Firstly, therefore, we witness the construction of the "new left" on the social front which, appealing mainly to the urban middle class, emphasises the fight against all kinds of "prejudice", "discrimination", "intolerance", "bigotry", and "ethnocentrism". This results in social campaigns for LGBTQ rights, environmentalism, abortion, euthanasia, and a proimmigration stance. Such "progressiveness" logically results in its detachment from large sections of societies that have to strive to survive in the ever-growing pressures of a competitive world. At the same time, the state is looked to as a vade mecum for all kinds of social ills, as in the case of Sweden or Germany, where, instead of trade unions, church schools, mutual societies, and cooperatives, it is now the government and its departments that are to act as the "universal" parent.

Secondly, on the economic front the left has been notoriously slow, indeed entirely ineffective in addressing the threats presented by the ever-growing power of multinational companies and supranational institutions such as the World Trade Organisation, the International Monetary Fund, the European Central Bank, or the European Commission.

The liberal ideology, on the other hand, has been enjoying a steady rise in its influence on socio-economic systems across the globe from the late 1970 (including the time of Margaret Thatcher and Ronald Reagan) until the first decade of the 21st century. As an ideology, neoliberalism posits the withdrawal of the state from many of its basic functions (economy, public services, education, healthcare, housing, etc.) and the consequent faith that the hidden hand of the market will almost always regulate the provision of services in a more efficient manner. Neoliberals (neoconservatives, monetarists or the "WC" supporters) derive their unabashed criticism of the state and its role in society by drawing on Ludwig von Mises's and Friedrich Hayek's arguments which revolve around individual freedoms, especially those in the political realm. The major argument, as put forward by Hayek, being that: "The authority directing all economic activity would control not merely the part of our lives which is concerned with inferior things; it would control the allocation of the limited means for all our ends [emphasis by the author]. And whoever controls all economic activity controls the means for all our ends [emphasis by the author], and must therefore decide which are to be satisfied and which not. This is really the crux of the matter. Economic control is not merely control of a sector of human life which can be separated from the rest; it is the control of the means for all our ends [emphasis by the author].” (Hayek, 1944). 
Consequently, an argument has been put forward by both the Austrian School (Carl Menger, Eugen von Böhm-Bawerk, and Friedrich von Wieser) and the Chicago School (Milton Friedman, George Stigler, Ronald Coase, and Gary Becker) which proposes that the role of the state should be as small as possible. This appears to be one of the major areas of the lib-left alliance, and is what one might refer to as a "congruence of interests". This, however, seems to be contradictory once we recall the shift of values among the left-wing parties. The left with their progressive ideas, in the radical Marxist and revolutionary tradition, have been against the national state by definition. In a milder, social-democratic tradition it has been against the control over the individuals as exercised by traditional institutions such as the church, the family, or gender. In effect, contemporary liberals and left-wing ideologues strive for the same ends - the liberation of an individual from the traditional norms imposed by traditional institutions. This alliance is, however, of a tactical character, and to a large extent it can be characterised by its negative nature: tactical, in the sense that in the final analysis, the ends of the left are very different from those pursued by the neoliberals; negative, in the sense that both ideologies see nationalism, political sovereignty, and traditional values as major threats in the way of creating new, postmodern societies.

One needs to look no further than what has been discussed above, namely, CETA. On 15th February, 2017, after eight years of negotiations, the European Parliament finally voted by a large margin in favour of the agreement: 408 in support of CETA vs. 254 against, with 33 abstentions (European Parliament, 2017). Interestingly, the socialists were particularly in favour of the agreement: 174 socialists voted in support vs. 66 against (importantly, and against the instructions of their party group), with 13 abstentions (Euractiv, 2017)

The opening salvo of the S\&D position paper on globalisation also leaves no doubts as to the alliance's take on the processes of globalisation: "Definitions of what Globalisation is vary immensely. Nevertheless, no matter how we define it, we must all acknowledge that Globalisation is now not only a process; it is a fact of life for citizens, workers, companies and countries alike. Drivers of globalisation such as enhanced trade, investment and disruptive technological change is [sic] impacting all parts of our lives and people all over the globe. Since all are impacted by it; all must come to benefit from it. That is the task we set for Europe in Harnessing Globalization" (Socialists \& Democrats in the European Parliament, 2017).

On top of this, one should keep in mind that according to Euractiv France, "barely a dozen sectoral agreements have been finalised since social dialog was established in Europe (enshrined in the Treaty Establishing European Community - author's comment). The social partners' contradictory objectives and the progressive disinvestment of the European Commission are to blame for this (Eractiv France, 2018).

\section{Clash of values and the integrative project in Europe}

Given the origins of European integration as well as the prominent position of socialists nowadays against the backdrop of the above-mentioned shift of the left-wing paradigm, one should query the axiological clash of values, which, in the assertion of the author of this paper, is leading directly to the crisis in European identity. 
This clash of values is seen in two realms: firstly, in the realm of religious influence, particularly the Christian norms established during the past millennium; and, secondly and consequently, in the economic realm where the two visions of capitalism (a neoliberal one and a regulated one) have been in collision since the late 1970 .

At first, European integration was a project very much based on Christian values (a sense of community and a common European identity). The founding fathers of European integration such as Alcide De Gasperi, Konrad Adenauer, and Robert Schuman ${ }^{6}$ were not only Catholics themselves but leaders of respective national political parties, commonly termed Christian Democratic (Linda, 2010). In this respect, the European Christian democratic parties supported the integration of Western Europe as a means of rebuilding the economies of their countries in the aftermath of the WWII. Like the Vatican, European Christian democrats envisaged European integration as a bulwark both against communism and against the threat posed by godless modern lifestyles. Their influence in European politics at the beginning of the 1950s was indeed outstanding. By that time the absolute majority of the MPs of the six founding members of the EEC were Christian democrats. They were also the largest single group in the assembly of the ECSC.

During Jacques Delores's tenure as head of the Commission (January 1985-December 1994), the first tangible efforts were made to establish regular links between the European Commission and religious and humanist groups. This process culminated in the formal establishment of the "Sole for Europe" initiative in 1994 which provided funds for ecumenical or inter-religious seminars for the elaboration on the meaning of European integration (Focas, 2009).

The 1968 revolt came to designate a turning point in the process of European integration. As Daniel Cohn-Bendit eloquently put it: "1968 was still a European movement. It had different motivations, but it happened in many places in Europe. And this anti-authoritarian rebellion gave rise to a new form of society all over Europe. Today we are on the path to a common identity" (Dülffer, 2008).

\section{European identity - the conundrum}

The current European identity stems from this axiological clash of values. On the one hand, the origins of European integration are of Christian provenance. On the other hand, since at least 1968, the gist of European integration has been increasingly characterised by individualism and the lack of a sense of traditional community (as defined by Christian democrats) fuelled by the ideologies of the 1968-revolt-based socialism and the early 1980 s neoliberalism. In this regard, 2004 and the so-called Big Bang enlargement also "took their toll". Apparently, as evidenced by the research carried out by Paul Copeland on negotiations surrounding the Working Time Directive and the Services Directive, new member states consistently joined the neoliberal coalition lead by the United Kingdom (Copeland, 2012). As he eloquently summarises: "European integration has long been viewed as featuring a clash of capitalisms with member states having a particular allegiance to either the liberal coalition or the regulated capitalism coalition. Divisions within the EU integration process can be located within a two-dimensional political space: the first dimension ranging from

\footnotetext{
${ }^{6}$ As of revision of this paper (March 2018) Robert Schuman is considered a Servant of God. His beatification process was commenced in 2004. See more: Rome reports at http://www.romereports.com/2013/12/22/robertschuman-a-european-politician-that-could-soon-be-declared-a-saint
} 
social democracy to market liberalism and the second from nationalism to supranationalism.”

What do we make of contemporary Europe and the current European identity, if there is such a thing at all? Since the 1980 os and the deregulation of the financial markets agenda, an observable trend has been for states to withdraw from their function and effectively outsource their capabilities to private for-profit companies. This trend has been referred to as "post-democracy" (Crouch, 2004). "The idea of post-democracy helps us describe situations when boredom, frustration and disappointment have settled in after a democratic moment; when powerful minority interests have become far more active than the mass of ordinary people in making the political system work for them; where political elites have learned to manage and manipulate popular demands; and where people have to be persuaded to vote by top-down publicity campaigns."

Similarly, Henry Giroux (2016) claims that neoliberalism as a mode of governance, produces identities, subjects and ways of life free of government regulations, driven by a survival of the fittest ethic, grounded in the idea of the free, possessive individual and committed to the right of ruling groups and institutions to accrue wealth removed from matters of ethics and social costs. As a policy and political project, neoliberalism is wedded to the privatisation of public services, the selling off of state functions, the deregulation of finance and labour, the elimination of the welfare state and unions, the liberalisation of trade in goods and capital investment and the marketisation and commodification of society."

This, arguably, has produces a sense of vagueness or even a lack of community. On the one hand, the left-wing parties seem to emphasise only some aspects of the European identity, such as tolerance and inclusiveness, and, on the other hand, neoliberalism mainly promotes consumerism instead of citizenship. As Matthew Goodwin (2015) accurately observes, clearly the liberals cannot present any coherent vision that would attract European societies en masse amid growing fears contrary to right-wing movements (often termed the "radical right" by the same liberals).

John Gray, of the London School of Economics, goes even further. In his interesting writings on contemporary liberalism, he identifies precisely the logical loopholes and lack of moral consequence as displayed by proponents of liberalism: "Today's liberals differ widely about how the wealth and opportunities of a market economy should be shared. What none of them question is the type of market globalisation that has developed over the past three decades. [...] That has come to be seen as a liberal principle: the right of everyone to assert what they take to be their identity particularly if it can be represented as that of an oppressed minority - by whatever means are judged necessary. If free speech stands in the way, the practice must be discarded. If terrorism is required, so be it." (Gray, 2016).

Gray identifies a new type of order which European societies seem to be entering out of the ideologically narrow framework of contemporary liberalism. He refers to it as: "a post-liberal order: [...] A post-liberal society is one in which freedom and toleration are protected under the shelter of a strong state. In economic terms, this entails discarding the notion that the primary purpose of government is to advance globalisation. In future, governments will succeed or fail by how well they can deliver prosperity while managing the social disruption that globalisation produces." 
Against this background, it is hardly surprising that European citizens have little faith in their own political elites, either at the national or the European levels. The last elections to the European parliament, in May 2014, attracted a record low turnout slightly above 40Recent parliamentary elections in the Netherlands, as well as the presidential and parliamentary elections in France, show that so-called liberal candidates had to "borrow" rightist/national rhetoric or even practices to secure their victories.

\section{Conclusion}

The shift of the political paradigm in European politics has had numerous consequences relevant to the European integration processes. Firstly, the left-wing parties, because of their acceptance of the globalisation paradigm, have turned away from their traditional electorate. Consequently, the left should rather be referred to as the "post-left".

As the German example shows, Christian Democrats (CDU), ahead of the last elections, were willing to abandon traditional (Christian) values and officially recognise samesex marriage. By the same token, other so-called conservatives in the EU have either agreed or are debating a more liberal approach to the issue. Discussions on abortion, euthanasia and the abolition of the death penalty have long featured in many EU member states, and this development prompts the author of this paper to claim that the conservatives should in fact now be termed "post-conservatives".

As a consequence, the mainstream political spectrum seems indistinguishable for the common voter, who turns against the political establishment (in the case of Emmanuel Macron in France) both nationally and across the EU. This is evidenced by the latest study coordinated by Chatham House, according to which: "there is a divide between elites and the public. There is alignment between the two groups in their attitudes to, among other things, EU solidarity, EU democracy and a sense of European identity. However, the data also show an important divide in general attitudes, beliefs and life experiences. The elite are more likely to experience the benefits of EU integration and are more liberal and optimistic. Meanwhile, there is simmering discontent within the public, large sections of whom view the EU in negative terms, want to see it return some powers to member states, and feel anxious over the effects of immigration" (Chatham House, 2017).

In other words, the left is not "leftist" enough, and the right is not "rightist" enough anymore. There seems to be an ideological emptiness, which affects the prospects of a European identity and with it integration of Europe. The reaction to such state of affairs seems to be rising populism and national sentiments. This is a sad state of affairs, where individuals can make fewer and fewer political choices, ones which in most cases are meaningless, and where the economic realities impose limitations upon whole generations rather than facilitate their development. As John Gray asserts: "Protecting liberty is not just a matter of curbing government, however. Rolling back the state in the economy and society can have the effect of leaving people less free - a fact that was recognised by liberal thinkers of an earlier generation" (Gray, 2016).

Both Henry Giroux and Colin Crouch are fundamentally in agreement when they assert that the biggest winners from globalisation and the biggest threats to the social order are private, usually multinational, companies. "As markets are touted as the driving 
force of everyday life, big government is disparaged as either incompetent or a threat to individual freedom, suggesting that power should reside in markets and corporations rather than in governments and citizens. Citizenship has increasingly become a function of market values, and politics has been restructured as 'corporations have been increasingly freed from social control through deregulation, privatization, and the neoliberal measures"” (Giroux, 2008).

Citizens in this regard simply become mostly consumers. The sense of their existence is reduced to ever-growing consumerism in order to satisfy the ever-growing demands and pressures of the economy. The monetisation and the marketization of their work, paralleled by growing competitiveness and automatisation/robotisation, are forcing whole sections of the societies of the so-called developed world to accept lower wages and less security (the "precariat"). Under such circumstances, the lending institutions of the financial world "come to the rescue". The effect, more often than not, is what the author of this paper refers to as "slavumerism" - a peculiar combination of slavery (debt bondage) and consumerism.

\section{Bibliography}

Alliance for Lobbying Transparency and Ethics Regulation (29th September, 2016). Retrieved from https://www.alter-eu.org/sites/default/files/documents/ALTEREU\%20Barroso\%20Complaint\%20Sep\%202016.pdf

Angier, T. (2015), Why European Social Democracy Is In Danger Of Terminal Decline. Social Europe. Retrieved 2 February 2015, from

https://www.socialeurope.eu/2015/o2/european-social-democracy-dangerterminal-decline/

Barigazzi, J. (2017), Vote on Five Scenarios for the Future of Europe. POLITICO. Retrieved 23rd March, 2017 from http://www.politico.eu/article/treaty-of-romeanniversary-vote-on-the-eus-future/

Bartholomeusz, J. (23rd March, 2017). Juncker's White Paper Has the Answers - and That is the Great Tragedy. Heinrich Böll Stiftung. European Union. Retrieved from https://eu.boell.org/en/2017/o3/23/junckers-white-paper-has-answers-and-greattragedy

Cann, V. (3oth January, 2017). Crowding the corridors of power: corporate lobbyists outnumber NGOs and unions in the European Parliament by 60\%. LobbyFActs.eu Retrieved from https://lobbyfacts.eu/articles/30-01-2017/crowding-corridorspower-corporate-lobbyists-outnumber-ngos-and-unions-european

Carrel, P. \& Shalal, A. (3oth June, 2017). German lawmakers approve same-sex marriage in landmark vote. Reuters. World News Retrieved from https://www.reuters.com/article/us-germany-gay-marriage-idUSKBN19LoPQ

CETA: MEPs back EU-Canada trade agreement. News European parliament (15th February, 2017). Retrieved from http://www.europarl.europa.eu/news/en/pressroom/20170209IPR61728/ceta-meps-back-eu-canada-trade-agreement

Citizens Against CETA. (2017). Flawed Economics. Retrieved from http://citizensagainstceta.blogspot.hk/p/blog-page_7045.html 
Clark, B. (1998). Political Economy. A comparative Approach. $2^{\text {nd }}$ ed. Westport: Praeger, p. 34.

Copeland, P. (2012). EU enlargement, the clash of capitalisms and the European social model in Comparative European Politics, 10: 4, pp. 476-504.

Crouch, C. (2004). Post-Democracy. Cambridge: Polity Press, pp. 19-20.

Davies, W. (2014). The Limits of Neoliberalism: Authority, Sovereignty and the Logic of Competition. London: SAGE Publications Ltd, p. 6.

De Grauwe, P. (2013). Design Failures in the Eurozone: Can They Be Fixed? LEQS Paper No. 57. Retrieved 12 February, 2013 from http://dx.doi.org/10.2139/ssrn.2215762

Dobbert, St. (6th June, 2017). Wir müssen die EU-Kommission abschaffen. ZEIT ONLINE. Retrieved from http://www.zeit.de/politik/ausland/2017-05/guyverhofstadt-eu-kommission-zukunft-forderung-abschaffung

Dülffer, M. (2008). 1968 - a European movement? Euro|topics. Retrieved from http://archiv.eurotopics.net/en/home/presseschau/archiv/magazin/geschichteverteilerseite-neu/achtundsechzig-2008-03/debatte-1968-2008-03/

Economic prosperity based on a flawed computer model (19th November, 2013). Retrieved from https://docs.google.com/document/d/1tehqlL8BFDrheDJP230wu1VsxfM6wrrqMO RqE-M8Lyk/edit

EP Plenary session: Joint debate - EU-Canada CETA. Round of political group speakers. Gianni PITTELLA (S\&D, IT) (9:45 - 9:49) (15th February, 2017). Retrieved from http://audiovisual.europarl.europa.eu/Assetdetail.aspx?id=6049c211-76db4871-aa2f-a71boo95d1d5

European Commission, 2017. EU Citizenship Report 2017. Strengthening Citizens' Rights in a Union of Democratic Change. Retrieved from: http://ec.europa.eu/newsroom/just/item-detail.cfm?item_id=51132

European Commission, 2017. White Paper on the future of Europe: Reflections and scenarios for the EU27 by 2025, pp. 8-9. Retrieved 1 March, 2017 from https://ec.europa.eu/commission/sites/betapolitical/files/white_paper_on_the_future_of_europe_en.pdf

EU employees, Petitioning President of the European Commission Jean-Claude Juncker and 2 others. For strong exemplary measures to be taken against JM Barroso for joining Goldman Sachs. Retrieved from https://www.change.org/p/for-strongexemplary-measures-to-be-taken-against-jm-barroso-for-joining-goldman-sachsinternational

European Commission, Economic and Financial Affairs. The EU Economy at the crossroads. Pathways to Enhances cohesion. Integration and Prosperity. Flagey, Brussels - 1st June, 2017. Retrieved from http://ec.europa.eu/economy_finance/bef2017/index_en.htm 
Fokas, E. (2009). "Religion: Towards a Postsecular Europe?” in Chris Rumford ed., The SAGE Handbook of European Studies. Los Angeles: SAGE, p. 408.

Geist, M. (25th October, 2016). The devil's in CETA's details, specifically on dispute settlement, The Globe and Mail. Retrieved from

https://www.theglobeandmail.com/report-on-business/rob-commentary/the-devilsin-cetas-details-specifically-on-dispute-settlement/article32492826/

Giroux, H. (2008). Against the Terror of Neoliberalism. Politics beyond the age of greed. London: Routledge, p. 2.

Giroux, H. \& Salamavicius. A. (2016). Higher education and neoliberal temptation. Retrieved from http://www.eurozine.com/pdf/2016-05-04-giroux-en.pdf

Gotev, G. (16th February, 2016) French and German socialists divided by CETA vote. Euractiv.com. Retrieved from:

http://www.euractiv.com/section/elections/news/french-and-german-socialistsdivided-by-ceta-vote/

Goodwin, M. (16th November, 2015). Paris Attacks: Liberals Must Fight the Far Right, or They'll Win. [expert comment]. Chatham House. The Royal Institute of International Affairs. Retrieved from

https://www.chathamhouse.org/expert/comment/paris-attacks-liberals-must-fightfar-right-or-they-ll-win?gclid=CL-WovfqkcoCFVgnvQodsgYD9Q

Gray, J. (7 November, 2016). The closing of the liberal mind. The folly of the masses has replaced the wisdom of crowds as the dominant theme of our politics. New Statesman. Retrieved from

http://www.newstatesman.com/politics/uk/2016/11/closing-liberal-mind

Hargreaves, R. (6th September, 2016). Here's how George Soros broke the Bank of Thailand. Business Insider. Retrieved from http://www.businessinsider.com/howgeorge-soros-broke-the-bank-of-thailand-2016-9

Harnessing globalisation: 10 overarching S\&D priorities. Group of the Progressive Alliance of Socialists and Democrats in the European Parliament (26th April, 2017). Retrieved from http://www.socialistsanddemocrats.eu/position-papers/harnessingglobalisation-10-overarching-sd-priorities

Hayek, F. (1944). The Road to Serfdom. London: Routledge Press, p. 95.

Heywood, A. (2002). Politics. $2^{\text {nd }}$ ed. Houndmills: Palgrave Macmillan, pp. 58-59.

Linda, R. (2010). "Cracks in Façade of Unity: The French and Italian Christian Democrats and the Launch of the European Integration" in Lucian N. Leustean \& John T. S. Madeley, eds. Religion, Politics and Law in the European Union. London: Routledge, p. 94.

Mounier-Kuhn, A. (January 24, 2018). The End of European Labour Agreements. Euroactiv France. Retrieved from: https://www.euractiv.com/section/economyjobs/news/the-end-of-european-labour-agreements/ 
Nugent, N. (2010). The Government and Politics of the European Union. $7^{\text {th }}$ ed. London: Palgrave Macmillan, p. 21.

Pittella, G. (15th February, 2017). 8) EP Plenary session: Joint debate - EU-Canada CETA. Round of political group speakers. Gianni PITTELLA (S\&D, IT) (9:45 - 9:49). European Parliament. Audiovisual Service for Media Retrieved from http://audiovisual.europarl.europa.eu/Assetdetail.aspx?id=6049c211-76db-4871aa2f-a71bo095d1d5

Robert, A. (2016).'Strange' maneuvering over CETA exposes democratic deficit. Euractiv. Retrieved 13th October, 2016from http://www.euractiv.com/section/tradesociety/news/strange-maneuvering-over-ceta-exposes-democratic-deficit/

Rustin, M. (2016). The crisis of neoliberalism in Europe. Prospects for European solidarity, post-Brexit. Eurozone. Retrieved 11 July 2016 from http://www.eurozine.com/the-crisis-of-neoliberalism-in-europe/

Śliwiński, K. (2016). 'A-securitization' of immigration policy - the case of European Union, Asia-Pacific Journal of EU Studies, 14:1, 25-56.

Soros, G. (2017). Remarks at the Brussels Economic Forum, p. 4. Retrieved 1 June 2017 from http://ec.europa.eu/economy_finance/bef2017/media/speech/2-sorosbef_en.pdf

Staab, A. (2011). The European Union explained. Institutions, actors, global impact. $2^{\text {nd }}$ ed. Bloomington: Indiana University press, p. 14.

Standard European Barometer 85 on EU citizenship from Spring 2016. Retrieved from http://ec.europa.eu/COMMFrontOffice/publicopinion/index.cfm/Survey/getSurveyDetail/instruments/STANDARD/surveyKy/2130

Stiglitz, J. E. (2016). The Euro and its Threat to the future of Europe. Penguin Random House UK. Kindle ed., loc. 189 of 7641.

Tansey, R. (2017). The creeping privatisation of healthcare. Problematic EU policies and the corporate lobby push. Corporate Europe Observatory. Exposing the power of corporate lobbying in the EU. Retrieved 2nd June, 2017 from https://corporateeurope.org/power-lobbies/2017/06/creeping-privatisation-healthcare

The Euro, European Union, Europa, about the EU, Money and the EU (2017), Retrieved 19 June 2017 from https://europa.eu/european-union/abouteu/money/euro_en

The Future of Europe. Comparing Public and Elite Attitudes. Chatham House. The Royal Institute of International Affairs (20th June, 2017). Retrieved from https://reader.chathamhouse.org/future-europe-comparing-public-and-elite-attitudes

The Greens/European Free Alliance, (2017). 12 Reasons the Green/EFA Group is Opposed to CETA. Retrieved 12 January 2017, from Http://Ttip2016.Eu/Blog/Id-12Reasons-The-Greenefa-Group-Are-Opposed-To-Ceta.Html

Treaty establishing the European Economic Community, 1957, p. 3. 
Verhofstadt, G. (2017). Europe's Last Chance. Why the European States must form a more perfect Union. New York: Basic Books. Kindle ed., loc. 410 of 4650.

Vincenti, D. (2016). EU employees set to hand in petition against Barroso. EurActiv.com. Retrieved 12th October, 2016 from http://www.euractiv.com/section/public-affairs/news/eu-employees-set-to-hand-in-petition-against-barroso/

Vincenti, D. (2016). Schulz makes a plea to back EU-Canada trade deal. Euractiv. Retrieved from 20 October, 2016 http://www.euractiv.com/section/tradesociety/news/schulz-makes-a-plea-to-back-eu-canada-trade-deal/

What is the problem with corporate lobbying? Alliance for Lobbying Transparency (20th July, 2017). Retrieved from https://www.alter-eu.org/what-is-the-problem 